\title{
THE RECONSTRUCTION OF ARMENIAN IDENTITY IN TURKEY AND THE WEEKLY AGOS*
}

\section{BASKIN ORAN}

\begin{abstract}
I delivered this paper in March 2002 at the Turkish-Armenian conference in Ann Arbor, Michigan.

"A lot of water has run under the bridges", as we say in Turkish, to mean that a lot has happened since I read it at that date.

I'll not go into it because Agos has come to be internationally known since the loss of my great friend (and editor-in-chief) Hrant. I'll only say this much:

Agos is now 24 pages, is sold throughout Turkey, is widely followed and respected in intellectual circles, is available on the Internet. Hrant has founded this paper, has placed it right in the middle of the Turkish ordeal for real democracy, and made it famous by his death. Martyrs accomplish more after they pass away.
\end{abstract}

\section{KEYWORDS}

Armenian identity, Agos, nationalism, minorities.

*The title of this paper was inspired by a seminar paper in French prepared by Mehmet Timuc,in Hastas, student at Marmara University in Istanbul, for the academic year 1997-98, under the direction of Associate Professor Fusun Ustel: Agos ou La Reconstruction de I'Identite Armenienne. 


\section{Introduction: The Road to the Birth of Agos}

Since about five or six years the Armenian identity in Turkey has been going through a very radical process of reconstruction.

This non-Muslim minority, to use the terms of the Lausanne Peace Treaty of 1923, has started to participate in the country's politico-cultural life very actively.

Every other day one of the community members writes in the newspapers or speaks at the TV channels.

Bookstore shelves are full of story books or novels by some twenty Turkish-Armenians writing in Turkish.

Armenians are running in municipal elections and one of them is now vice-mayor of Sisli, Istanbul.

Since a few years, the Armenian Patriarcate has been servicing e-mail news to a growing list of intellectuals.

Nowadays no CD with a title like "Anatolian Folk Songs" is recorded without one or more song in Armenian. A folk song group called "Knar" that started as a church choir has produced two CDs, "Anadolu Ermeni Türkiileri" (Armenian Songs of Anatolia) and "Anadolu'dan Kafkasya'ya Ermeni Müzigi" (Armenian Music from Anatolia to the Caucasus). As much important was the fact that a joint album by Gasparian (the most famous "duduk" player, Armenian national instrument) and Erkan Ogur (the most famous "kopuz" player, Turkish national instrument from Central Asia) made it to the best selling list; music critics unanimously felt that it was a "must".

In a recent movie about the notorious Wealth Tax of 1942 CSalkim Hanim'in Taneleri") a folk song called Sari Gelin (The Blond Bride) was sang in both languages, and the high level of the discussion that followed about the ethnic origin (Turk or Armenian?) of the song could not even be dreamed of just a few years ago. 
One last and most surprising case is about Eddie ("Edi" in Turkish), an Armenian boy about 20 years of age. Crossing his heart and speaking in Armenian to himself in difficult moments during the entire program, Edi was declared by the public jury the winner of the very popular TV program "Biri Bizi Gozetliyor" (Someone's Watching Us), the Turkish version of "Big Brother" in the US or the "Loft Story" in France..

These developments that would be sheer dream just a while ago have three important qualifications: First, the Community is entering the socio-political scene of Turkey, openly, with its own identity, ${ }^{1}$ and in a way to influence the national agenda strongly when the political atmosphere is rather unfavorable. Second, this process is making a vital contribution to Turkey's democratization process mainly under EU's influence. Third, this change of skin is paralleling to the recent developments of international human and minority rights.

The weekly Agos (in Armenian: trace of the plow) that started this process and that now plays the role of both its steering wheel and engine has been the outcome of certain particular needs, which should be examined carefully.

Students of minorities know it well: Minorities formed by immigration easily integrate to their new country and even get assimilated. This is the position of Pomak, Bosnian, Circassian, etc. communities in Turkey. Those who resist to the dominant culture of the country are those autochthonous populations, peoples living on the land since time immemorial and getting their strength from being on their historical territory; this is the position of the Rum $\left({ }^{\wedge} \mathrm{Hellenes}\right.$ of the Ottoman Empire and of Turkey) and Kurds of Anatolia.

Although Armenians were one of these few autocthonous peoples, they perfectly integrated. The reason was twofold:

'Armenians had always been on the artistic and scientific scene but with Muslim-Turkish names, not with their own identity. 
One, unlike the Rum, the Armenians were not the heirs of a universal empire; they were also somehow isolated as a result of having seceded from the Orthodox Church at the Khalkedon Council of 451 and their particular alphabet also separated them from the rest of the Christendom. Consequently they perfectly integrated to the Ottomans, generally spoke Turkish at home, took Turkish family names by adding "/an" (son of) to it, gave innumerable artists, scientists, and administrators to the Empire, and very actively contributed to its modernization. ${ }^{2}$ As a result, in an Empire where the Turks (Turcomans) revolted very frequently, Armenians never caused any problem well until the second half of the $19^{\text {th }}$ century (after 1821 they were called Millet-i Sadika - The Faithful Nation).

Second, as a result of living on Silk and Spice roads, the Armenians had dwelled in handicrafts and trade, and the Ottomans encouraged them to go and settle in Istanbul to counterbalance the allpowerful Rum community and also let them set up an autocephalous Patriarchate in Istanbul in 1461.

In time, mainly four factors destroyed this harmony:

1) Oppression and exploitation of the administrators and of Kurdish/Circassian tribal leaders (suzerains) became unbearable as a result of the weakening of the central government in a period when the industrial goods of the West invaded and impoverished the market, slowly killing the handicrafts; 2) Great impact of 1789 ideas on the emergent Armenian petty bourgeoisie middle class of Anatolia and of Diaspora; and also the class conflict between this rising bourgeoisie and the Amira, Armenian aristocrat-grand bourgeois class; 3) Provocations by the Great Britain and Russian Empire among the Armenian petty bourgeoisie with a view to use the latter in the European power struggle called the Eastern Question; 4) The grudge of the Ottomans unable to accede to mercantilism against those who did (the non-Muslims), and also the matching grudge that Muslims (Millet-i Hakime, the Dominant Nation) started to feel against the non-Muslims when the latter became their theoretical equals by virtue of Tanzimat (1839) and Islahat (1856) firmans.

${ }^{2}$ For example Ohannes Odyan Efendi was Prime Minister Mithat Pasa's council in the preparation of the first constitution in 1876. 
These four factors created a milieu in which Armenians of Anatolia started armed organizations in a view to obtain territorial autonomy; hence the start of mutual killings in Anatolia.

This created panic and reaction in Istanbul. A syndrome of disintegration slowly developed because unrest in the Balkans had now spread to the eternal enemy (Russian) border and also because the actor was now the Faithful Nation, which was confessionwise very close to the Russians. In this atmosphere, Abdulhamit II set up the notorious Hamidiye Regiments to curb the Armenian uprisings.

The dramatic drop of the curtain took place in the chaos of the First World War. For the Ottomans, who after the loss of the Balkans immediately faced the shocks of Sarikamis (Caucasus) and Dardanelles, the terrible feeling was that the Empire would soon be driven back to its cradle, Anatolia where the Armenian revolutionaries now cooperated with the advancing Russians. This chaotic socio-psychological atmosphere created an ideal milieu of relative administrative autonomy for a nucleus among the panTurkist Ittihat ve Terakki Party to get rid of the Armenians who were also blocking the road to Turan, Central Asia; hence the notorious Tehcir (deportation) of $1915 .^{3}$

$$
* * *
$$

${ }^{3}$ This nucleus can be translated in the terms of contemporary Turkey as the "Derin Devlet", the Deep State usually identified as "Gladio" in Europe (see interviews by Halil Berktay in the newspapers Radikal, 09 October 2000 (www.radikal.com.tr) and Milliyet, 20 October 2000 (www.milliyet.com.tr) . On the other hand, because it was conducted by this "Deep State" and not by "the State", the Deportation did not follow a standard model. In some vilayets it was not applied. In some places people backed it up, in some hindered it. But the fact that Armenians owned big properties that local notables and tribes could plunder has been detrimental. The fear that Armenians would return and retake their property according to Sevres Peace Treaty art. 144 was also the strongest reason why these same notables and tribes in eastern Anatolia sided with Ankara against the Allies and Greeks during the Turkish war of independence. See B. Oran, ed., Tiirk Di\$ Politikasi, Kurtulu§ Sava§indan Bugiine Olgular, Belgeler, Yorumlar (Turkish Foreign Policy, Facts-Documents-Comments, 1919-2001), Vol. I, Istanbul, iletisim Publishers, December 2001, p. 133-134. 
The Armenian population in the Republic of Turkey in 1923 was 300.000, 170.000 of which in Anatolia and 130.000 in Istanbul. This figure is around 50.000-80.000 now. This dramatic fall points to a large scale migration from Anatolia to Istanbul and from there to the West.

Aside from the fact that material conditions were far better in the West, the real reason of this exodus was the negative impact on the Community of certain braking points. Although the Ataturk period (1923-38) was relatively peaceful, these major braking points, such as the notorious Varlik Vergisi (Wealth Tax) of 1942, Yirmi Kura Askerlik (Work Battalions), 6-7 September 1955 riots and the 1964 deportation of the Greeks, ${ }^{4}$ caused serious unrest among the Armenian community.

In this atmosphere the Community isolated itself from the majority and started a secluded life to protect its identity. But incidents of the next three decades were to prove that this selfisolation was no remedy for the protection of communal integrity.

As a matter of fact, in the 1970s the Armenian nationalist organization ASALA started to kill Turkish diplomats, which yielded two important results: First, a very strong reaction in Turkey against ASALA, which was generalized as "Armenian terror" without distinction as to who the "Armenian" was. Second, the Armenians of Turkey who had absolutely nothing to do with this terror entered in a depressive mood, which greatly augmented their self-isolation. One of the dramatic outward expressions of this psychology was the selfcremation of a member of the Community, Artin Penik, in Taksim, the main square of Istanbul.

1980s witnessed the intensification of this atmosphere when the notorious 12 September military coup strongly backed the "Turkish-Islamic Synthesis" to replace the Leftist ideology. Shaken by the ASALA terror, Turkish State and media went to the search of

\footnotetext{
${ }^{4}$ The first two of these regrettable incidents were acts of open discrimination against non-Muslims, the last two had targeted the Rum in an unfair endeavor to influence/punish Greece because of the Cyprus issue.
} 
"Armenian Lackeys" behind the Leftist organizations, never qualifying the expression "Armenian". What's more, immediately after ASALA quitted the stage because its last bombing in the Orly airport in Paris (July 1983) created strong European reaction as it killed Europeans also, the Kurdish nationalist organization PKK started the terror in 1984. This was inevitably interpreted by everyone in Turkey as the Leftist, Armenian, and Kurdish organizations taking a coordinated row in a race to split Turkey. In this fight, soon degenerated into an undeclared civil war, the State and the media did not want to identify PKK with Turkish citizens of Kurdish origin and started to declare that the PKK leader Ocalan ("Apo") was no Kurd but Armenian. We even know that at the time, an academic from Ankara was commissioned to search the family tree of Ocalan (apparently, with no positive result). The capture of some noncircumcised PKK militants was enough to spread the contention that "Armenian militants" were fighting in the PKK. ${ }^{5}$ The photo of Ocalan with a cleric declared to be an Armenian priest and published in the large selling daily Sabah completed this picture.

Finally, in the 1990s, the Armenian community of Turkey was shaken by a brand new problem. The USSR had disintegrated, Armenia declared its independence and soon after invaded Nagorno Karabag, an Armenian-majority region of Azerbaijan. At this time Turkey had recognized the Republic of Armenia along with other exSoviet republics and was even giving this country electric power and wheat. But after it became clear that the invasion was not temporary, a strong reaction came to settle in the Turkish public opinion, and relations were severed as a result of pressures from the public opinion and Azerbaijan. This meant more enmity towards the "Armenians".

In all these cases, the term "Armenian" was used without any qualification and therefore Armenians of Turkey felt accused. This term soon became an insult in the media and was also used by the Minister of Interior herself as Ermeni Dölti (the Armenian Sperm).

Every time this happened, the self-isolation of Armenians of Turkey was further accentuated. Some hardliners of the "TurkishIslamic Synthesis" in the Ministry of National Education found this

${ }^{5}$ See my Devlet Devlete Kar\$i, Ankara, Bilgi Publishers, 1994, p.23-26. 
milieu very profitable and went so far as to abolish the use of Armenian language in Armenian minority schools (Lausanne Treaty, art. 40). However, the democrat circles in the media strongly reacted and this right was restored a week later. ${ }^{6}$

\section{I) Agos: Its Publication, Objectives, Structure, Content, and Style}

\section{Publication}

On 22 April 2001 the daily Cumhuriyet published, on the sixth anniversary of Agos, an interview with the latter's redactor-in-chief, Hrant Dink, who tells about the story of this publication:

"Everything started when the Patriarch Karekin II invited a few friends over. It was the years 1994-95. There was something that bothered him a lot. Certain false news in the Turkish press were linking Armenians of Turkey with the PKK. The picture of Ocalan with an Armenian priest published in the front page of Sabah was presented as the proof of this cooperation. The reporting was fabricated, the Patriarch was helpless, and the note he sent to the newspaper had not been published. He asked us what should be done. (...) We all pointed out the following: The fact that the Community was closed to outside world and therefore was unable to express itself to the greater society was a great handicap. This could not go on like this. This secluded life was unable to save the Community from melting. There should be some kind of opening. The method should be setting up a dialogue with the Turkish press".

In other words, the start of Agos took place in a totally negative atmosphere. On the other hand this showed how "dialectics", in that sense that everything bears within its very negation, was meaningful: The Armenians of Turkey had to really be in trouble to destroy the shell that imprisoned them.

\section{Objectives}

Hbid., p. 13-22. 
After the meeting, the group organized a press conference and explained that the priest on the photo was not an Armenian cleric. The press was very interested and the group decided to hold monthly meetings with the media. The final decision was to found a newspaper in Turkish. In the same interview H. Dink explains the reasons:

1) The need to defend the Community point of view when needed, and also introduce the Armenians of Turkey to the national public opinion.

2) The younger generation and those who came to Istanbul from Anatolia don't speak Armenian and we can overcome this only with a newspaper in Turkish.

3) It's very difficult to raise intellectuals in a Community that uses Armenian only and we need a "kitchen" to open the channels.

These considerations found their reflection in the zero issue of Agos published on 25 February 1996. The first issue appeared on 5 April 1996. This date was also the Armenian Easter known as Surp ("Saint") Zadik; it symbolized the rebirth of the Community, and the Patriarch Karekin II had saluted the publication as "a gift of Surp Zadik" in this first issue.

\section{Structure}

Careful about their autonomy, the founders of Agos did not look for a sponsor and founded the paper by contributing each 3-5000 dollars and thus collecting some 18-20.000 dollars for a start; they also got about the same amount in credits. The publication was started thanks to the voluntary help of a few Turkish professionals as the group originally had only one professional journalist among them. As a non-profit organization, the weekly can currently stand on its feet with the revenues of subscription, sale and advertisements.

Agos started with 8 pages and sold 1.800 copies. It is now 12 pages, 3 in Armenian and 9 in Turkish, and sells 6.000. Of these, 1000 copies are sold to non-Community circles in Turkey, 2000 in various foreign countries, and the rest to the members of the Community and also at newspaper stands in various cities. It can also 
partly be read on the Internet (www.agos.com.tr). In the same interview, H. Dink says the best readers of Agos are "those who burn in the Diaspora with the Anatolian nostalgia", as a result of which the weekly has subscribers in all continents.

The founders of Agos are between 30 to 60 years of age. All of them are university graduates, left (in US terminology: liberal) wing intellectuals who mainly are critical both of the Community and the State.

The personnel of Agos which includes two most senior journalists of the Community, Yervant Gobelyan and Hagop Ayvaz, is composed of about 30 salaried people, except the editor-in-chief who doesn't get paid. Its columnists include three non-Armenians. The personnel is mostly composed of college students and also youngsters studying journalism. Since the foundation some 90 of them worked for Agos and are now working in various publications of the national press.

\section{Content and Style}

The following is a list of the main subjects treated on first page:

1) News depicting and answering any accusations against the Community, whichever source these may come from (the State, media, individuals, etc.). Main examples of these are those news, reports, etc. criticizing the State's unfair treatment of Armenian foundations (waqf) and especially those pertaining to the "1936 Declaration". ${ }^{7}$

\footnotetext{
${ }^{7}$ This document which is an accomplished specimen of economic discrimination against Armenian foundations in Turkey is abundantly treated in many issues of Agos. See for instance my "Dinsel Aynmcihkta Evelallah Kararhyiz" (Thanks God We Are Resolutely Decided in Religious Discrimination), Agos, 04 January 2002. Also my Lausanne Ihlalleri, Turkiye He Yunanistan Aqisindan Karsilasitirmah Bir Inceleme (The Lausanne Violations, A Comparative Study on Turkey and Greece), unpublished report, 1999.
} 

AND THE WEEKLY AGOS

2) Human rights violations and problems of democratization in Turkey.

3) Main developments in the Republic of Armenia and in Caucasus, especially those pertaining to Turkey-Armenia relations and more particularly to the dialogue between the two countries.

4) The current situation of Armenian cultural heritage that contributed to the Ottoman Empire and Turkey, its importance, and any mistreatment these may encounter. Serials like "Bir Zamanlar" (Once Upon A Time) and "Ermeni Kadim Tarihi" (Armenian Ancient History) are cases in point which detail the Armenian existence in Anatolia before the First War.

5) Malfunctions in Community institutions and the non-transparency of their administration.

Agos is treating these subjects in a mild but determined style, and criticizes them by offering alternatives. The Patriarchate is not spared in these critics. Agos is generally critical of the current state of affairs in the Community and thinks it is not transparent enough. It strives to put an end to the isolation of the Community and it wants the Community to open to Turkish society with self-confidence.

Agos, which follows very closely all acts unfair to the Community, keeps its cool when the media overacts "in defense of the Armenians". For instance, it carefully examines a media news about a "Senior citizen unable to get a free bus pass from the municipality because he is a non-Muslim" and writes that it is an "asparagas" (intentional false news). In fact, we learn that the false news was spread by the mayor of another municipality. ${ }^{8}$

\section{II) Main Observations, Theses, Methods, and Objectives of Agos}

\footnotetext{
8"Paso Haberi Doğrulanmadi" (The Bus Pass Incident Is Not True), Agos, 07 January 2000.
} 
Up till now Agos had many observations and theses that did not coincide with those of the Community and of the Diaspora, and were even contrary to them. These can be summarized as follows:

1) Turkish language should be preferred to Armenian for many reasons. Because the majority of the Community doesn't know enough Armenian to follow newspapers in this language and is therefore isolated from the Community. On the other hand, not using Turkish isolates him from the national majority.

2) The future of the Community is not promising, because the self-isolation that pushes it away from the majority cannot protect its identity. With the effect of globalization youngsters suffer slow and natural assimilation. The Community must open itself to the national society.

3) The main issue is to be able to get rid of the fear of assimilation. Once free from it, members of the Community will be more realistically able to protect their identity and make themselves accepted by the majority. The contemporary tendency is anyway towards integration with the society at large without getting assimilated into it.

Agos is trying to materialize this courageous observations and theses by publishing both in Armenian and Turkish. The 12-page weekly's 3 pages in Armenian symbolize: "We'll not be assimilated", and the 9 pages of Turkish: "We want to get integrated".

4) To reach this important and delicate objective, two main prerequisites must be realized:

First, to underline the important contributions of the Armenian heritage to the common Anatolian culture at the same time with opening to the Turkish society at large. This aim is being materialized also by publications other than Agos nowadays. In the last five years or so over 60 books are published about the Armenians of Turkey by Turkish writers and the Aras Publishing House, run by Armenians. The most recent of these is a 865-page book in very large format, written by Arsen Yarman on "Osmanli Saglik Hizmetlerinde Ermeniler ve Surp Pirgig Ermeni Hastanesi Tarihi" (Armenians in 
Ottoman Health Services and the History of Saint Pirgic Armenian Hospital) and published by the said Hospital.

Second, Armenians should be able to get rid of the residues of the past and look at the problems through the eyes of the other side (the majority) as well. In other words, Armenians should be able to display empathy. This will incite the majority to act the same.

This second observation, which $\mathrm{H}$. Dink expressed by saying "Turkish-Armenian relations should be taken out of a 1915 metersdeep well", ${ }^{9}$ is of great importance, because it is a hundred per cent against the genocide thesis of the Diaspora and the Republic of Armenia. In this context empathy has nothing to do with accepting or refusing the genocide.

According to Agos, the genocide discourse is not a historical term but a political one. It is cherished by the Diaspora for two important reasons: First, it is a "national cause" that hinder its assimilation; second, it increases its political influence in the host State. But the same discourse is blocking both the Turkish-Armenian dialogue and the integration that is in the good interest of Armenians in Turkey. What's more, this blocking is being made while the Turkish intellectuals have started questioning 1915 in every way. Everyone should abstain from blocking a dialogue that would for sure be beneficial to everyone (the Diaspora, Republic of Armenia, Turkey).

5) The main methods to be used to get integrated without getting assimilated should be as follows:

First: To criticize the wrongs done by the State and underline the fact that a strong Turkey would be achieved if discrimination is eliminated. This should be done with seriousness, and a very careful and legally clear style.

Second: To criticize and therefore strengthen the Community. This will be made possible by criticizing three groups of individuals

${ }^{9}$ H. Dink, "Diaspora'nin Köyii-2" (Diaspora's Village-2), Agos, 14 April 2000. 
or groups: 1) Those who mismanage the Community institutions; 2) Those who don't care to struggle to obtain rights by legal ways ("They can't take away your rights as long as you don't surrender them"10); 3) Those for whom nothing seems enough. That is to say, those who are never happy with the rights that the Community obtains and who are rather inclined to refuse its non-perfect gains. After all, this is a country that is very reluctant to concede rights to its majority as well.

Third: In order to continue to be influential and constructive, Agos should be very careful not to take sides between conflicting parties, i.e. between the Community and the State, between various institutions of the Community, between the State on one side and the Diaspora and the Republic of Armenia on the other. A good example of this is H. Dink's article entitled "23,5 Nisan" (23,5 April). ${ }^{11}$

Fourth: Armenians of Turkey should rely on internal dynamics instead of external dynamics. ${ }^{12}$ In history, Armenians have been used and abused over and over again, and have always been left to themselves by the big powers when calamity arrived. Internal dynamic (democracy) works much slower in this country and is much more painful, but it's much safer and lasting.

FiveFifth: The rights of the Armenian community should not be constructed on the axis "Protection of Minorities" as expressed in articles 37-44 of the Lausanne Peace Treaty (^positive rights under international guarantee), but on "Prevention of Discrimination" (=negative rights=democracy). And this is so, for the simple fact that positive rights approach founded on international guarantee isolates the minority, sterilizes it in a milieu where it cannot protect its identity either, and identifies them as a target. Democratic rights

\footnotetext{
${ }^{10}$ H. Dink, "Ne Yapmali?" (What's To Be Done?), Agos, 23 November 2002.

${ }^{11}$ Agos, 26 April 1996. 23 April is Children's and National Sovereignty Day in Turkey, while 24 April is taken as the symbol of Armenian massacres.

12"Dear Mr. President", ibid.
} 
founded on the "guarantee of Turkish public opinion" are more secure. $^{13}$

As to the founding objectives of Agos, H. Dink says in the same Cumhuriyet interview: "We reached well beyond our objectives in proportions we themselves have not expected" and explains:

1) Communication in the Community has developed considerably. For instance, 16.000 participated to the last Patriarchal elections while 5-6.000 had voted in the previous one.

2) Agos has succeeded to build a "kitchen" and has even raised many journalists.

3) It successfully introduced the Community to the Turkish society. Nowadays when any information about the Community is needed, it's Agos that people come to. So much so that, now there is a real need for an Institute of Armenian Studies.

4) We set up links with many Turkish writers. Now we have many friends. They automatically speak in defense of us any time the need arises.

5) We can even say that an unpredicted mission has fallen upon us: The setting up of a dialogue between Turkey and Armenia, between Turkish and Armenian peoples. We are most pleased to try to work for it.

\section{Conclusion}

The weekly Agos is published with an approach very different from what the Armenian community had shown earlier. It has applied mild but determined methods to solve the chronic problems accumulated during the self-isolation days of the Community.

During its six years of publication so far, Agos has followed a neutral line that criticize both the State and the Diaspora.

\footnotetext{
13"Haydi Tilrkiye Birliğine" (Let's Walk to the Turkish Union), Agos, 17 December 1999 (this is an editorial published after Turkey was declared a candidate to the European Union).
} 
It has not feared the Turkish State when it openly criticized its unfair policy of discrimination and resolutely defended its identity in an undemocratic atmosphere. As a matter of fact the newspaper was twice banned from circulation, as the State was not used to and/or prepared for such a different and determined approach. ${ }^{14}$

On the other hand Agos has not feared the possibility of being considered by the Diaspora as a "Fifth Column" either, for resolutely refusing to accept the genocide approach, and for opting for a voluntary integration into the Turkish society.

In this picture, Agos is perfectly in line with the contemporary approach to human and minority rights and thus greatly contributes to the democratization process of Turkey. But its most important contribution to its host State resides in the fact that it brings, without knowing it, the only possible solution to Turkey's greatest problem, the Kurdish Question, by offering a model founded on resolute insistence on its lower identity while voluntarily accepting the country's upper identity.

${ }^{14}$ Agos was finally acquitted in both cases. The first of these articles is Yervant Ozuzun's "Aci Bir Kilometre Tasi ve Kiiltür Kinmi" (A Regrettable Milestone and a Cultural Massacre), Agos, 13 November 1998; it was an article on the Wealth Tax of 1942. The second is H. Dink's "Bir Gün... 24 Nisan" (One Day... 24 April), Agos, 20 April 2001; it said that Armenian genocide discourse would no longer be a problem the day when it would be possible for the Armenians of Turkey to commemorate 24 April. 